\title{
Evaluation of Green Areas of Konya Selçuklu, Bosna-Hersek Neighborhood in Terms of Sufficiency, Management and Usage ${ }^{\#}$
}

\author{
Serpil Önder ${ }^{1, a, *}$, Ruhugul Ozge Gemici ${ }^{1, b}$, Ahmet Tuğrul Polat ${ }^{1, \mathrm{c}}$ \\ ${ }^{1}$ Department of Landscape Architecture Faculty of Architecture and Design, Selcuk University, 42130 Konya, Turkey \\ *Corresponding author

\begin{tabular}{|c|c|}
\hline R T I C L E I N F O & B S T R A C T \\
\hline $\begin{array}{l}{ }^{\#} \text { This study was presented as an online } \\
\text { presentation at the } 2^{\text {nd }} \text { International } \\
\text { Journal of Agriculture - Food Science } \\
\text { and Technology (TURJAF 2021) } \\
\text { Gazimağusa/Cyprus } \\
\text { Research Article }\end{array}$ & $\begin{array}{l}\text { Green areas are spaces organized as areas where people can get rid of their monotonous lives and } \\
\text { meet their active or passive recreation needs. In order for a society to be physically and mentally } \\
\text { healthy, green spaces must fulfil the purposes of establishment. The main material of the research } \\
\text { is the green areas of Bosna-Hersek neighbourhood. The questionnaire method was used in the study } \\
\text { and the green areas in Konya province Selçuklu district Bosnia and Herzegovina neighbourhood } \\
\text { were evaluated in terms of sufficiency, management and usage }\end{array}$ \\
\hline
\end{tabular}

Received : 03/11/2021

Accepted : 26/11/2021

Keywords:

Bosna-Hersek neighborhood

Green areas

Konya

Landscape planning

Open Areas

\section{Introduction}

Due to rapid and irregular urbanization, construction, lack of infrastructure, continuous migration and similar concepts in the traditional planning approach in Turkey, green areas develop independently of the planning expectations and goals of the urbanization processes. The social and cultural realities that Turkey is in and the illegal settlements that result from these create an urban texture determined by eclectic formations more than anything else. This typified urban texture, which is valid for many settlements, causes the insufficient green areas and the formation of green areas that do not meet the expectations of contemporary urban life in terms of design standards (Aksoy, 2001).

It determines the general character of a city, architectural structures, open-green areas and their relations and integrity with each other. Open-green areas have an important position in balancing the deteriorating relationship between human and nature and improving urban living conditions. For this reason, the quality and quantity of open-green areas in developed countries are accepted as an indicator of civilization and quality of life. In this context, many developed countries are trying to plan and create suitable urban space or ecology for human life, taking into account the mental and physical needs of people (Gül ve Küçük, 2001).

This study was carried out in open-green areas in Konya province Selçuklu district Bosna-Hersek neighborhood. Bosna-Hersek neighborhood is the second largest neighborhood of Selçuklu district of Konya province with a population of 36,998 . This study was carried out to determine the adequacy of open-green areas and reinforcement elements in the neighborhood. In addition, within the scope of the research, results related to the management and use of open-green areas were also obtained. Suggestions have been developed in line with the results obtained.

\section{Open-Green Areas}

Urban open and green areas are defined in two groups as active green areas and other green areas in the Zoning Law No. 3194. active green spaces; parks and recreational areas, playgrounds and playgrounds designed for the direct benefit of the society. Other green areas are; These are 
areas that the public can use directly or indirectly, but generally do not have the functions of active green areas. They can be used naturally within the residential areas or they can be arranged by human hands. The main green areas in cities can be listed as follows: Forest areas, afforestation areas, bushes, public or private gardens, fairs, fairs and festival areas, cemeteries, etc. (Kahraman, 1999).

Open-Green areas are areas consisting of living and non-living elements such as parks, cemeteries, refuge areas, forests, groves and building gardens of various functions and sizes, located in and around the city, which have functions such as recreation, landscaping and hydrology (Pamay, 1978).

Open-green areas are common areas of use, surrounded by buildings in the urban fabric or surrounding building blocks, where all urban events are associated and open to everyone's use (Küçükerbaş ve Özkan, 1999).

Open-green areas provide people to benefit from the open and clean air, children to play safely, and young people to play and do sports. It is also defined as parks, playgrounds and playgrounds arranged with plant material in a conscious and planned manner, and places arranged as groves, forests and picnic areas in or around the city (Çalışkan, 1990).

Open-green areas, which contain the openings outside the architectural structures in the urban texture, massive and fragmented greenery, water surfaces, keep the development of the city under control, undertake unifying and separating functions, ensure the integrity of the city in general, and apart from all these, they are primarily ecological due to their existence. It is called as a set of systems that provide some features such as aesthetic, recreational and economic (Öztan, 1991).

\section{Classification of Open-Green Areas}

It is also possible to classify urban green spaces in terms of use, hierarchy and function. According to the way of use, green areas are divided into three groups as public open-green areas, semi-private open-green areas and private open-green areas. Urban and neighborhood parks, sports fields, urban forests, woodlands, botanical gardens, zoos, fair and exhibition areas; semi-private open-green areas, schools, factories, public institutions and establishments gardens and military areas; On the other hand, private open-green areas are privately owned housing and collective housing gardens (Gül Küçük, 2001).

According to the hierarchy, it is possible to classify green areas under 5 groups as housing level, neighborhood level, neighborhood level, city level and regional level green areas (Manavoğlu, 2013).

In terms of their functions, green areas are divided into active and passive green areas. Park areas, children's playgrounds and sports areas that are open to the benefit of the society are expressed as active green areas. passive green spaces; protection, aesthetics, etc., which are not available to the public. are green spaces organized for the purpose. Private gardens, agricultural areas, fruit orchards, non-public commercial groves and nurseries, state forests, cemeteries, military areas, school and hospital gardens, sports facilities areas, security lanes and medians on roads and squares within the building parcels are within the scope of passive green areas (Manavoğlu, 2013).

\section{Functions of Open-Green Areas}

Open-green areas have a great impact on the psychological rest, recreational activities and sociocultural development of the urban people. Open-green areas, which are a strong element of the aesthetic and architectural form of cities, are important not only ecologically, but also because they provide social cohesion, fuel social development, and support economic purposes and activities (Etli, 2002).

Open-green areas allow cities to maintain their relationship with nature, offering different activities for people of all ages. For this reason, its importance for the citizens should not be ignored. Existing open-green areas should be protected and new buildings should be planned and designed to meet the needs of users both in size and functionality (Erbatmaz, 1999).

\section{Planning of Open-Green Areas}

Planning is the process of preparations, decision making and selection before taking action in order to reach a conceptually determined goal. Planning is a process of forecasting for the future (Manavoğlu, 2013).

The purpose of urban open and green areas planning is to meet the active and passive recreational demands of the urban people; to ensure the regular establishment of cities and to control development; to place the uses that will serve different purposes in cities on urban land in an appropriate, sufficient and systematic use of space; to create aesthetic and functional areas (Manavoğlu, 2013).

Every city is an organism with a different identity and character, and it is not possible to implement a standard green space planning for every city. In order to meet the need for open and green areas, the topographic structure and climate characteristics of the cities, the use of land, the natural landscape features and beauties, the social and cultural structure, the number and structure of the people, the density of use, the type and density of settlement, the need for open and green areas. The required area potential, the character and identity of the city are the factors that should be considered in the planning and implementation of an open and green area system suitable for the structure of the city (Manavoğlu, 2013).

In order for the physical structure of the city to be balanced, open and green areas should be adequately planned for the total population and their distribution within the city should be suitable for the density of the city (Manavoğlu, 2013).

\section{Materials and Method}

\section{Materials}

Research material consists of research area and research tools and materials. The research area is opengreen areas within the borders of Konya province, Selçuklu district, Bosna-Hersek neighbourhood.

In addition to the research area, the following research materials were also used:

- Literary documents consisting of various books, ebooks, journals, articles, theses, reports and internet sites on the subject, including domestic and foreign studies,

- Resources related to the research areas obtained from Konya Governorship, Selçuklu District Governorate, Konya Metropolitan Municipality, Selçuklu 
Municipality, Konya Provincial Directorate of Culture and Tourism,

- $\quad$ Questionnaire forms applied to people who use open and green areas, which were originally prepared for the research.

\section{Method}

The method of the research consists of three stages: Preliminary preparation, data collection, analysis and evaluation.

In the preliminary stage: Studies such as collecting preliminary information about the subject, collecting conceptual and theoretical information, determining the research topic and field, and establishing the research hypothesis were carried out.

At the stage of data collection and analysis: The preparation of survey forms related to the analysis of the current situation of the research area and the application of these survey forms to the users were carried out.

In the evaluation phase, discussions on the functions of open and green areas, evaluation of the questionnaires, and giving the results and suggestions were carried out.

\section{Preparation of surveys}

Within the scope of the research, questionnaires were prepared in order to determine the current situation of open and green areas, to get the opinions of the people who use these areas on the current status of the open and green areas, their usage patterns, the uses and functions that should be included. In the preparation of the survey questions, the findings obtained at the stage of obtaining preliminary information and similar studies conducted in line with the literature were used.

\section{Determination of Sample Size}

The number of people the survey will be applied to is determined by the formula given below. The population size of the Bosna-Hersek neighborhood is 36,998. When this information is applied to the formula below, the sample size is 96. In this case, the questionnaires should be applied to at least 96 people. The number of surveys we applied to people who use the open-green areas of Bosna-Hersek neighborhood is 100 .

$$
n=\frac{N p(1-p)}{(N-1) \sigma_{p x}^{2}+p(1-p)}
$$

$\mathrm{n} \quad=$ Sample volume

$\mathrm{N}=$ Number of businesses in the population

$\sigma_{\mathrm{px}}^{2}=$ The variance of the ratio

$\mathrm{p}=0.5$ tolerance

\section{Implementation of Surveys}

The questionnaires were applied to people who use the open and green areas of Bosna-Hersek neighborhood between May 2019 and June 2019.

\section{Analysis of Surveys}

While analysing all the questionnaires applied within the scope of the research, Google Forms were used. In addition, Microsoft Office 2016 program was used while preparing the study.

\section{Research Results and Discussion}

\section{General Characteristics of the Research Area}

Geographical location and description of the study area: Bosna-Hersek neighborhood is located in the northern periphery of the city of Konya, on the east of Yeni Istanbul Street, which is the main transportation axis of Konya-Istanbul, connected to the Konya Selçuk Municipality, approximately $20 \mathrm{~km}$ from the city center. It is located on the east side of Selçuk University, Alaeddin Keykubat Campus. It is bordered by Aliye İzzet Begoviç Street and Yukarıpınarbaşı District in the north and east, the new Istanbul street and Selçuk University in the west, and Kosova and Büyükkayacık Districts in the south. Aliya İzzet Begoviç Street, which forms the northern line of the Bosna-Hersek neighborhood, connects the Ankara road to the Istanbul road. While the altitude of the district center is $1020 \mathrm{~m}$, the altitude of the Bosna-Hersek neighborhood is $1105 \mathrm{~m}$ and it is mostly flat (Eğlen, 2015).

Climatic condition: Continental climate prevails in Selçuklu district of Konya province. Summers are dry and hot, winters are cold and snowy. The temperature difference between night and day is between 16-22 degrees in summer. In spring and winter, this difference decreases to $9-12^{\circ} \mathrm{C}$ due to humidity. Snow stays on the soil surface for an average of 3 months. Although it is located in the southernmost region of Central Anatolia, it is colder than other Central Anatolian cities. The reason for this is that the middle Taurus completely avoids the sea effect (Anonim, 2021a).

Flora: There has been a natural plain steppe in Central Anatolia since ancient times (Çetik, 1985). Selçuklu district and Bosna-Hersek neighborhood have the characteristics of Central Anatolia in terms of vegetation.

Founding of the neighborhood: Located in the Selçuklu district of Konya, this neighborhood was established in 1993 with the decision taken by the Konya Metropolitan Municipality Council and the name of the neighborhood was given in line with the decision taken in the parliament. Aliya İzzet Begoviç who is the President of Bosnia and Herzegovina at that time, came to the establishment of the neighborhood and made the opening himself (Anonim, 2021b).

Physical Structure: Bosna-Hersek neighborhood has all the physical characteristics of its district, and there is no regional difference. The neighborhood of Bosna-Hersek, surrounded by two main arteries (Ankara and Istanbul streets), has been adopted as a living space by university students and staff in a short time and has become an important residential area due to the existence of Selcuk University Alaeddin Keykubat Campus (Eğlen, 2015).

Transportation: Transportation in Bosna-Hersek neighborhood is provided by minibus, municipal buses and trams. Cycle lanes exist in designated areas but are not widely used. In the city information system, it is seen that there are alternative transportation plans for the neighborhood of Bosna-Hersek, and new public transportation lines will be created for the outer walls of the neighborhood (Eğlen, 2015).

Population: According to the address-based population registration system in 2020, the population of Konya is $2,250,020$ people. The annual population growth rate is 8.7 $\%$ and the number of people per square kilometer is 56 . The population of the city center is $1,359,251$ people (Anonim, 2021c). 
Social structure: Bosna-Hersek neighborhood built as a slum prevention zone in 1993, is a neighborhood detached from the city, consisting of low-quality cooperative housing, appealing to the lower-middle income group and deprived of urban services. When it was first established, local residents, mainly from the rural areas of Konya, continued to practice their rural habits (small-scale cultivation, animal husbandry) in the area. In the first years of the establishment of the neighborhood, most of the houses were left empty as no tenants could be found, and the neighborhood went through a development process parallel to the development process of the university (along with the studentization process) (Tuncer ve İslam, 2017).

\section{Users' Evaluations on Adequacy, Management and Use of Open-Green Areas}

Demographic characteristics of the people surveyed

$47 \%$ of the respondents are female and $53 \%$ are male. $13 \%$ of the respondents are in the range of $0-18,28 \%$ are in the range of $19-25,21 \%$ are in the range of $26-35,19 \%$ are in the range of $36-50,11 \%$ are in the range of 51-65. In addition, $8 \%$ are over 65 years old. $1 \%$ of the respondents are illiterate. $22 \%$ of them are primary school, $29 \%$ high school, $43 \%$ university and $5 \%$ graduate. $39 \%$ of the respondents are students, $10 \%$ are civil servants, $7 \%$ are self-employed, $12 \%$ are unemployed, $14 \%$ are housewives, $13 \%$ are workers and $5 \%$ are retired.

Adequacy status of open-green areas in Bosna-Hersek neighborhood

Those who find the amount of open-green area in the Bosna-Hersek neighborhood very sufficient is $12 \%$. People who find the amount of open-green area sufficient is $61 \%$. Those who are undecided about whether the amount of open-green area is sufficient is $13 \%$. People who find the amount of open-green area insufficient is $13 \%$. People who find the amount of open-green area very insufficient is $1 \%$.

The percentage of people who find the parks in BosnaHersek neighborhood very adequate is $17 \%$. People who find the parks sufficient are $49 \%$. The people who are undecided about whether the parks are sufficient are $21 \%$. People who find the parks inadequate is $11 \%$. People who find the parks very inadequate is $2 \%$.

The percentage of people who find the official institution gardens in the Bosna-Hersek neighborhood very adequate is $6 \%$. People who find public institution gardens sufficient are $41 \%$. People who are undecided about whether public institution gardens are sufficient are $35 \%$. People who find public institution gardens insufficient are $16 \%$. The people who find the official institution gardens very inadequate is $2 \%$.

The rate of people who find the car parks in BosnaHersek neighborhood to be very sufficient is $15 \%$. People who find the car parks sufficient are $48 \%$. Those who are undecided about whether the parking lots are sufficient are $18 \%$. The people who find the car parks insufficient are $18 \%$. People who find the car parks very inadequate is $1 \%$.

The percentage of people who find the playgrounds in Bosna-Hersek neighborhood very adequate is $8 \%$. People who find the children's playgrounds sufficient are $43 \%$. Those who are undecided about whether children's playgrounds are sufficient are $27 \%$. People who find children's playgrounds insufficient are $21 \%$. The percentage of people who find children's playgrounds very inadequate is $1 \%$.

The percentage of people who find the sports fields in Bosna-Hersek neighborhood very adequate is $9 \%$. People who find the sports fields sufficient are $37 \%$. The people who are undecided about whether the sports fields are sufficient are $18 \%$. The number of people who find the sports fields insufficient is $26 \%$. The percentage of people who find the sports fields very inadequate is $10 \%$.

The rate of people who find the benches found in the open green areas of Bosna-Hersek neighborhood very sufficient is $11 \%$. People who find the benches sufficient are $46 \%$. Those who are undecided about whether the benches are sufficient are $12 \%$. People who find the benches inadequate are $27 \%$. People who find the benches very inadequate is $4 \%$.

The rate of people who find the gazebos/pergolas found in the open green areas of Bosna-Hersek neighborhood very sufficient is $15 \%$. The rate of people who find pergolas/pergolas sufficient is $42 \%$. People who are undecided about whether the pergolas/pergolas are sufficient are $16 \%$. The number of people who find the arbours/pergolas inadequate is $22 \%$. The rate of people who find the arbours/pergolas very inadequate is $5 \%$.

The rate of people who find the garbage cans found in the open green areas of Bosna-Hersek neighborhood very sufficient is $7 \%$. The rate of people who find the garbage cans sufficient is $33 \%$. 14\% of people are undecided about whether the trash cans are sufficient. The people who find the garbage cans insufficient are $28 \%$. The people who find the garbage cans very inadequate is $18 \%$.

The percentage of people who find the lighting elements found in the open green areas of Bosna-Hersek neighborhood very sufficient is $17 \%$. People who find the lighting elements sufficient are $45 \%$. Those who are undecided about whether the lighting elements are sufficient are $14 \%$. People who find the lighting elements insufficient is $16 \%$. People who find the lighting elements very inadequate is $8 \%$.

The percentage of people who find the flower boxes in the open green areas of Bosna-Hersek to be very sufficient is $8 \%$. The rate of people who find the flower boxes sufficient is $35 \%$. Those who are undecided about whether the flower boxes are sufficient are $14 \%$. People who find the flower boxes insufficient is $20 \%$. The number of people who find the flower boxes very inadequate is $23 \%$.

The rate of people who find the direction/information signs in the open green areas of Bosna-Hersek neighborhood very sufficient is $8 \%$. The rate of people who find the guidance/information signs sufficient is 55\%. $14 \%$ of people are undecided about whether the direction/information signs are sufficient. The rate of people who find the direction/information signs insufficient is $18 \%$. The rate of people who find the direction/information signs very inadequate is $5 \%$.

The percentage of people who find the fountains in the open green areas of Bosna-Hersek neighborhood very sufficient is $12 \%$. The people who find the fountains sufficient are $45 \%$. Those who are undecided about whether the fountains are sufficient are $20 \%$. People who find the fountains insufficient are $17 \%$. People who find the fountains very inadequate is $6 \%$. 


\section{Management of open-green areas in Bosna-Hersek neighborhood}

People who find the open-green areas of Bosna-Hersek neighborhood very well-kept are $17 \%$. People who find open-green areas well-maintained are 54\%. People who are undecided about finding open-green areas well-maintained are $11 \%$. People who find open-green areas uncared for are $17 \%$. People who find open-green areas very neglected are $1 \%$.

People who feel very safe while spending time in the open-green areas of Bosna-Hersek are $17 \%$. People who feel safe while spending time in open-green areas are $46 \%$. $20 \%$ of people are undecided about whether they feel safe or not while spending time in open-green areas. People who do not feel safe while spending time in open-green areas are $15 \%$. Those who do not feel safe while spending time in open-green areas are $2 \%$.

Usage status of open-green areas in Bosna-Hersek neighborhood by users

The people who use the open-green areas of BosnaHersek every day are $12 \%$. People who use it several times a week are $30 \%$. People who use it once a week are $22 \%$. People who use it every 15 days are $20 \%$. People who use it several times a month are $13 \%$. People who use it several times a year are $12 \%$. Those who use it once a year are $2 \%$. Those who never use it are $1 \%$.

People who spend less than 1 hour in the open-green areas of Bosna-Hersek are 26\%. People who spend between 1-3 hours are $49 \%$. People who spend time between $3-5$ hours are $22 \%$. Those who spend more than 5 hours are $3 \%$.

$2 \%$ of people say that the elderly are taken into consideration in the structural and plant applications in the open green areas of Bosna-Hersek neighborhood. The rate of people who say that the elderly are taken into consideration is $45 \%$. Those who are undecided on the subject are $21 \%$. Those who say that the elderly are not taken into account are $24 \%$. The percentage of people who say that the elderly are not taken into consideration is $8 \%$.

The rate of people who say that the disabled are taken into consideration in the structural and plant applications in the open green areas of Bosna-Hersek neighborhood is $0 \%$. The percentage of people who say that the disabled are taken into consideration is $25 \%$. Those who are undecided on the subject are $23 \%$. People who say that the disabled are not taken into consideration is $29 \%$. People who say that the disabled are not taken into consideration are $23 \%$.

\section{Conclusion and Recommendations}

As a result of the surveys, it is seen that the people who find the open-green areas in Bosna-Hersek neighborhood are in the majority. $73 \%$ of the people surveyed think that open-green areas are sufficient. However, in order to ensure that this rate is higher, the presence of green areas in the neighborhood should be increased. It should not be forgotten that green areas are very important for both the physical and mental development of people.

When the parks, public institution gardens and car parks in Bosna-Hersek neighborhood are evaluated in terms of adequacy, it is seen that the parks are $67 \%$, the official institution gardens $47 \%$, and the parking lots are $63 \%$. Considering these results, which cannot even exceed $70 \%$, it is understood that the number of parks and car parks in the neighborhood should be increased, and the official institution gardens should be developed and the amount of green area in these gardens should be increased.

When the results of the survey conducted for the equipment elements in Bosna-Hersek are evaluated, the surveyed people use children's playgrounds $51 \%$, sports fields $46 \%$, benches $57 \%$, arbors/pergolas $57 \%$, garbage cans $40 \%$, lighting elements $62 \%$, flower boxes $2 \%$. 43 , found direction/information signs $63 \%$ and fountains $57 \%$ sufficient. Considering the ratios, it is seen that the reinforcement elements are not fully sufficient in the neighborhood. By working in this direction, the number of reinforcement elements in the neighborhood should be increased.

People who find the Bosna-Hersek neighborhood clean and well-maintained are $71 \%$, and $63 \%$ find the neighborhood safe. According to these results, it is a fact that the neighborhood administration should be more attentive. In addition, some arrangements should be made taking into account the elderly and disabled people who use the neighborhood. Because it is thought that landscaping arrangements made considering the elderly are $47 \%$, and landscaping arrangements made considering the disabled are $25 \%$.

\section{References}

Aksoy Y. 2001. İstanbul kenti yeşil alan durumunun irdelenmesi. Basılmamış Doktora Tezi, İ.T.Ü. Fen Bilimleri Enstitüsü, İstanbul.

Anonim, 2021a. Tarım ve Orman Bakanlığı Meteoroloji Genel Müdürlüğü. https://www.mgm.gov.tr/veridegerlendirme/il-veilceler-istatistik.aspx?m=KONYA (Erişim Tarihi: 20.10 .2021 )

Anonim, 2021b. Bosna Hersek'ten Orta Anadolu'ya uzanan kültür köprüsü: Konya Selçuklu Bosna-Hersek mahallesi örneği. https://docplayer.biz.tr/14447212-Bosna-hersek-ten-ortaanadolu-ya-uzanan-kultur-koprusu-konya-selcuklu-bosnahersek-mahallesi-ornegi.html (Erişim Tarihi: 20.10.2021)

Anonim, 2021c. Konya İl Kültür ve Turizm Müdürlügü. http://www.konyakultur.gov.tr/index.php?route=pages/pages \&page_id=4 (Erişim Tarihi: 20.10 .2021$)$

Çalışkan, A. M. (1990). 3194 Sayılı imar yasası açısından kentlerimizde açık-yeşil alan sisteminin geleceği ve ankaraçankaya ilçesi örneği. Yüksek Lisans Tezi. Ankara Üniversitesi Fen Bilimleri Enstitüsü Peyzaj Mimarlığ Anabilim Dalı, Ankara.

Çetik AR. 1985. Türkiye vejetasyonu: İç Anadolu'nun vejetasyonu ve ekolojisi. I. Selçuk Üniversitesi Yayınları, No: 7, s:496, Konya.

Eğlen AB. 2015. Konya Bosna-Hersek mahallesi rekreatif alanlarının mimari yönden değerlendirilmesi. Yüksek Lisans Tezi. Selçuk Üniversitesi Fen Bilimleri Enstitüsü Mimarlık Anabilim Dal1, Konya.

Erbatmaz E. 1999. İzmir ili gaziemir ilçesi mevcut alan kullanım kararları ve açı yeşil alanların saptanması üzerine bir araştırma. Yüksek Lisans Tezi. Ege Üniversitesi Fen Bilimleri Enstitüsü Peyzaj Mimarlığı Ana Bilim Dalı, İzmir.

Etli B. 2002. Edirne ili merkez ilçe yeşil alan sisteminin peyzaj mimarlığı ilkeleri yönünden irdelenmesi, Trakya Üniversitesi, Bilimsel Araştırmalar Dergisi, Edirne.

Gül A, Küçük V. 2001. Kentsel açık-yeşil alanlar ve isparta kenti örneğinde irdelenmesi. Süleyman Demirel Üniversitesi, Orman Fakültesi Dergisi, A(2), 27-48.

Kahraman GN. 1999. Kayseri kentsel gelişme alanının peyzaj planlama kapsamında değerlendirilmesi. Y. Lisans Tezi. Çukurova Üniversitesi, Fen Bilimleri Enstitüsü, Peyzaj Mimarlığı Ana Bilim Dalı, Adana. 
Küçükerbaş EV, Özkan MB. 1999. Kemalpaşa kentsel dış mekanların irdelenmesi. Kemalpaşa Kültür ve Çevre Sempozyumu. 03-05 Haziran, Kemalpaşa-İzmir.

Manavoğlu E. 2013. Antalya kenti yeşil alanlarının çok ölçütlü analizi ve planlama stratejilerinin geliştirilmesi. Doktora Tezi. Akdeniz Üniversitesi Fen Bilimleri Enstitüsü, Peyzaj Mimarlığı Anabilim Dalı, Antalya.
Öztan Y. 1991. Ankara kentinin 2000'li yıllar için açık ve yeşil alan sistemi olanakları. Peyzaj Mimarlığı Dergisi, Sayı:2, 32 36, Peyzaj Mimarlığı Derneği Yayınları, Ankara.

Pamay B. 1978. Kentsel peyzaj planlaması. İ.Ü. Yayınları, İ. Ü. Yayın No:2487, Orman Fakültesi Yayın No:265, İstanbul.

Tuncer T, İslam T. 2017. Yeni bir soylulaştırma formu olarak öğrencileştirme (studentification): Bosna-Hersek Mahallesi'nde (Konya) değişen mahalle içi dinamikler. Planlama 2017;27(3):303-313. 